British \& Irish Botany 2(3): 261-263, 2020

\title{
Nomenclature of the white-flowered variant of Viola reichenbachiana (Violaceae)
}

\author{
M.J. Porter ${ }^{1}$; M. Foley ${ }^{2}$; L. Lewis ${ }^{3}$ \\ ${ }^{1}$ Wigton, Cumbria, UK; ${ }^{2}$ Blackburn, Lancs., UK; ${ }^{3}$ Chepstow, Monmouthshire, UK.
}

*Corresponding author: M.J. Porter: carexmike@yahoo.co.uk

This pdf constitutes the Version of Record published on $31^{\text {st }}$ August 2020

\begin{abstract}
The white-flowered variant of the Early Dog-violet hasn't been validly published under the specific epithet Viola reichenbachiana. We name it here as Viola reichenbachiana Jord. ex Boreau var. leucantha (Beck) M.S. Porter, M.J.Y. Foley \& L. Lewis.
\end{abstract}

Early Dog Violet is fairly common in most of Britain and Ireland though scarce in the far north and south-west of England and very rare in Scotland. It is also found throughout mainland Europe, in NW Africa and as far east as Iran. Its accepted scientific name is Viola reichenbachiana Jord. ex Boreau, syn. $V$. sy/vestris auct. Lam. (Sell \& Murrell, 2018; Tropicos, 2020). It is somewhat similar to $V$. riviniana in general appearance but differs in its darker, generally unnotched spur, the slight reddish cast in the flower colour, its narrower upper petals, the scarcely branched veins on the spur petal and the proportionately narrower and more acutely tipped leaves (Fig. 1).

The flowers of $V$. reichenbachiana are normally violet. However, the BSBI Viola Handbook states: "Several colour variants have been recorded but only one, sometimes called var. leucantha Beck, is normally seen and this only rarely. The corolla is usually pure white with obscure veining on the lowest petal. The spur is white" (Porter \& Foley, 2017). Although, as indicated in the Handbook, this white-flowered variant is sometimes called var. leucantha, the name $V$. reichenbachiana var. leucantha was not published by Beck. The name he actually published for plants with white petals was V. sy/vestris f. leucantha (Beck, 1893). The name $V$. sy/vestris subvar. leucantha was also published for plants with white or whitish petals by Rouy \& Foucard (1896), together with the name $V$. sy/vestris subvar. punctata for plants with a violet blotch at the base of the lower petal. This latter subvariety, but not subvar. or f. leucantha, was subsequently reclassified as a variety of $V$. reichenbachiana by P.D. Sell in Sell \& Murrell (2018). 


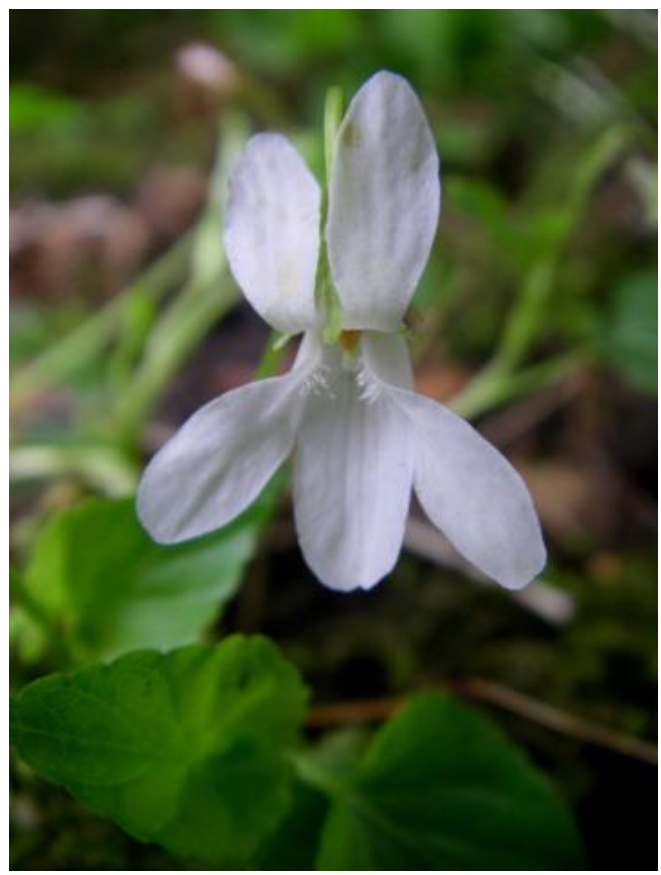

Figure 1. Viola reichenbachiana var. leucantha, Grubbins Wood, Cumbria, 14.04.2012. B.A. Tregale

As the name Viola reichenbachiana var. leucantha has never been validly published under the International Code of Nomenclature for algae, fungi, and plants (ICN), the only validly published names for the white-flowered variant are the now no longer accepted $V$. sy/vestris infraspecific names published by Beck and Rouy \& Foucard respectively. To rectify this, V. sy/vestris f. leucantha is now reclassified as a variety of $V$. reichenbachiana as follows:

Viola reichenbachiana Jord. ex Boreau var. leucantha (Beck) M.S. Porter, M.J.Y. Foley \& L. Lewis, comb. nov.

Basionym: Viola sy/vestris Lam. f. leucantha Beck, Fl. Nied.-Öst: 521 (1893). Synonym: Viola sy/vestris Lam. subvar. leucantha Rouy \& Foucaud, Fl. France 3: 13 (1896).

\section{Acknowledgement}

We are grateful to B. A. Tregale for permission to use his photograph.

\section{References}

Beck, G., Ritter von Mannagetta. 1893. Flora von Nieder-Österreich, $2^{\text {nd }}$ half. Vienna: Druck und Verlag von Carl Gerold's Söhn.

Porter, M. \& Foley, M. 2017. Violas of Britain \& Ireland, BSBI Handbook No 17. Bristol: Botanical Society of Britain \& Ireland. 
Rouy, G. \& Foucard, J. 1896. Flore de France ou Description des plantes qui croissent spontanément en France, en Corse et en Alsace-Lorraine, vol. 3. Asnières and Rochefort: Published by the authors.

Sell, P. \& Murrell, G. 2018. Flora of Great Britain and Ireland: Volume 1, Lycopodaceae - Salicaceae. Cambridge: Cambridge University Press

Tropicos.org. Missouri Botanical Garden. 2020. Viola reichenbachiana. http://legacy.tropicos.org

Copyright retained by author(s). Published by BSBI under the terms of the Creative Commons Attribution 4.0 International Public License.

ISSN: $2632-4970$

https://doi.org/10.33928/bib.2020.02.261 